\title{
Reproducing Elite Lives: Women in Aggarwal Family Businesses
}

\section{Ujithra Ponniah}

\section{(2) OpenEdition}

\section{Journals}

\section{Electronic version}

URL: http://journals.openedition.org/samaj/4280

DOI: $10.4000 /$ samaj.4280

ISSN: 1960-6060

\section{Publisher}

Association pour la recherche sur l'Asie du Sud (ARAS)

\section{Electronic reference}

Ujithra Ponniah, "Reproducing Elite Lives: Women in Aggarwal Family Businesses », South Asia Multidisciplinary Academic Journal [Online], 15 | 2017, Online since 09 March 2017, connection on 02 May 2019. URL : http://journals.openedition.org/samaj/4280 ; DOI : 10.4000/samaj.4280

This text was automatically generated on 2 May 2019.

\section{(c) (i) () $\Theta$}

This work is licensed under a Creative Commons Attribution-NonCommercial-NoDerivatives 4.0 International License. 


\title{
Reproducing Elite Lives: Women in Aggarwal Family Businesses
}

\author{
Ujithra Ponniah
}

I am grateful to Surinder Jodhka, Jules Naudet and A. G. Ponniah for their discussions and patient reading of repeated drafts. I thank the three anonymous reviewers for their incisive comments. I thank my respondents for their time and for inviting a stranger into their homes and lives.

\section{Introduction}

1 This article argues that women along with their families play a major role in the functioning of family businesses through the reproduction of caste and kinship ties in the urban context. Until 2005, women were denied the right to inherit property under the Hindu United Family (HUF), a legal tax entity (Das Gupta 2013). In the popular imagination, women appear as consumers of branded items indicative of luxurious lifestyles, while in the everyday, their choices, negotiations, and power struggles are lost within the undifferentiated gender-blind institution of the family. Family businesses have been the forte of old mercantile caste groups (Jains, Marwaris, Agarwal, Sindhi, Natukkotai Chettiar, Khoja, Bohra, Parsi). These caste groups have been categorized as "upper" caste because of their historically-accrued economic and political capital. This paper focuses on a non-Brahmin elite caste: Aggarwal. Aggarwals have a visible presence especially in parts of North India and are pushing to be at the helm of state and economic affairs. However, they are often confused with their popular cousins, the Marwari, who have a longer community history and have received more academic attention (Timberg 1978; Hardgrove 2004; Birla 2009).

2 Studies argue that caste and family ties structure Indian family businesses (Tripathi 1984; Markovits 2008; Damodaran 2008). In the absence of financial intermediaries, the structuring role of caste and family extends to corporate boards and networks in globalized contexts (Naudet and Dubost 2016; Daljit and Saxena 2012; Khanna and Palepu 2000). While studies argue for the centrality of caste and family ties in family businesses, they treat caste as a finished identity with an a priori subjecthood (Bairy 2010). 
This identity which presents itself as a universal is also male-centric. Caste in its substantialized avatar has internal hierarchies and distinctions (Fuller 1996). This classlike hierarchy has led scholars to argue that the lives of "upper"-caste members cease to be caste-marked, and secular concerns of class animate their being (Beteille 1991; Srinivas 2003; Gupta 2004; Fuller 1996; Fuller and Narshiman 2015). A simultaneous increase in caste studies on Dalits leads to a "ghettoization" of caste around the figure of the Dalit (Bairy 2010:2). Caste then becomes synonymous with Dalits while the upper caste becomes caste-less. Through a focus on an urban "upper"-caste group, the Aggarwal, this paper explores the following question: how does caste, with its internal hierarchies and urban secularizing pulls, function as a socio-economic resource in family businesses?

This paper ethnographically demonstrates how women in family businesses help increase the cohesion and reproduction of caste and families in "modern" contexts through three strategies: first, forging fictive kinship ties across caste strata through what elite women understand as their "social work"; second, forging fictive kinship ties within one's own caste stratum through sustained socialization that creates business opportunities; and third, helping to find status-appropriate marital matches factoring in the individuating desires of their children.

4 In-depth interviews were conducted with Aggarwal women in the 40s to 60s age group in an affluent South-Delhi neighborhood, which I will call Hill Lane. ${ }^{1}$ Roles in families are not just gendered but also vary according to one's age. Other members of the respondents' families (sons, daughters, and daughters-in-law) were also interviewed. Community and family events were attended. The first rounds of interviews were conducted from October 2014 to July 2015. The second round of interviews was conducted from March to July 2016, to confirm the main findings of the study.

\section{Methodology: field and researcher}

5 Amongst the neighborhoods of South Delhi, Hill Lane was selected as the field of study for the following reasons: post-holders and influential individuals in Aggarwal caste associations (Delhi Pradesh Aggarwal Sammelan (DPAS) and Akhila Bhartiya Aggarwal Sammelan (ABAS) in Delhi are based here; the women's wing is the oldest and the most active (it has won awards); and a tabulation of house-owners according to surname given in the Resident's Welfare Association (RWA) in 2014 shows that fifty-eight percent of residents in this neighborhood hail from the Aggarwal caste. Finding members of a caste group in urban residential pockets is corroborated by other studies in metropolitan cities (Dupont 2004; Vithayathil and Singh 2012). Caste-residential clusters for the lower caste can be read as segregation in which individuals have little choice. However, amongst the elite upper castes like the Aggarwal, the same phenomenon is the result of selfsegregation. In retrospect, this is motivated by the amenities available in the vicinity like proximity to established schools, safety in the knowledge that there are other Aggarwal also buying land in the same area and fair property prices. Unlike what is commonly imagined, the neighborhood amongst the urban elites does not lead to anonymity and isolation. Within the heterogeneous neighborhood, the Aggarwal choose who they wish to socialize with in their everyday activities. The neighborhood as a field of activity through the interaction of their class-and caste-status generated the feeling of Aggarwal-ness and "ourness." This was further asserted by naming public spaces after Maharaja Agrasen. ${ }^{2}$ 
6 Some of the Aggarwal families who live in Hill Lane had diversified out of the agrarian economy in their grandparent's generation and moved to Delhi for higher education. Many families had moved to this neighborhood by the 1970s, while the women moved from parts of Haryana, Uttar Pradesh or other parts of Delhi after marriage. They were now second- and third-generation industrialists with manufacturing units (metal and plastic molds, iron meshes, temperature-monitoring devices) on the outskirts of Delhi and families with inter-generational professional firms (architects, real estate and lawyers). The number of those employed in their factories and professional firms varied. The location and size of a house announce the "household identity and activity." It also "deeply affects subsequent self-representation and social relations outside the household and daily interaction within the household" (Zelizer 2005:243). According to the size and success of the business, families had well laid out houses with modern interiors, several servants and usually two to three cars. Floors were added to the house to accommodate the changes within the family. For example, if the family business was split between brothers and they were no longer on cordial terms, an extra floor was added with its separate entrance and kitchen. A separate floor was also added if the son in the family got married. However, then the kitchen continued to be common. Families also lived nearby in separate houses in the same neighborhood. Some of the Aggarwal family businesses in this neighborhood hold important positions in the Aggarwal caste associations and have been instrumental in building the Aggarwal community and identity in Delhi since the late 1970 s.

7 As I met people in different Aggarwal circles in Delhi, I realized it would be difficult to interview families in the upper strata of the Aggarwal caste without sharing an enthusiasm for their associational activities. There are close to twenty-four Hindi Aggarwal newspapers and journals that are published in Delhi. I subscribed to some of these established newspapers and followed them regularly. Community events like the release of books on Maharaja Agrasen, internal award ceremonies, the new caste associations being set up in Delhi, marches and rath yatra (chariot journeys), the inauguration of cow hospitals and organization of Ramlila, and lifestyle festivals ${ }^{3}$ were regularly advertised in these newspapers. Events like parichay sammelan (a matrimonial event) and politicians wishing the Aggarwals in Delhi well on Maharaja Agrasen Jayanti were found in mainstream English and Hindi newspapers. The national visibility shows the community's political and economic clout in the capital. Frequent meetings with people during these events gave me access to women and their families in Hill Lane.

8 The space of the caste associations and the events they organize in Delhi showed the different caste strata ${ }^{4}$ interacting with each other. Hindu religious events like Ramlila (a dramatic re-enactment of the Hindu god Ram's life, ending with a tense battle between Ram and his nemesis Ravana), gowshalas (cowsheds), hospital and temple trusts, schools and colleges were funded by the first stratum of Aggarwal. They reside in parts of Civil Lines, Anand Vihar, and Punjabi Bagh and are amongst the first to migrate to Delhi at the beginning of the $20^{\text {th }}$ century from parts of Rajasthan and Haryana (erstwhile Punjab). They migrated to Chandni Chowk which was the biggest wholesale market in India and referred to as the shehar (city). However, they slowly moved out of Chandni Chowk, as they found it was becoming overcrowded and its narrow streets too polluted. Finding a space to park was an issue. Some families also claimed they wanted to move, as they did not appreciate the increasing number of Muslim families in Chandni Chowk. ${ }^{5}$ They are referred to as Dili Walas (those who came to Delhi first and belong here) in inner circles. 
This reference distinguishes them as old and established families whose first generation had participated in the independence struggle. They are successful inter-generational family businesses and share a proximity with political leaders. They and their wives were however not visible in daily caste-association events. The second stratum are those living in parts of South Delhi, like the Aggarwal families in Hill Lane I describe above.

The third are those whose previous generation was involved in the agrarian economy, and they or their children migrated to Delhi around or after Independence. They attribute their move to the Partition and the ban on usury. ${ }^{6}$ Some of those who migrated to Delhi in the 1960s and 70s say it was because of a further weakening of their position in the agrarian economy after the Green Revolution, which led to the opening up of the "credit-production-trade" network and offered other avenues to secure a loan (Jodhka 1995). Some of them are first generation industrialists and live in parts of Pitampura, Rohini and Shalimar Bagh in North West Delhi.

10 The fourth are those that live across the river Yamuna in places like Laxmi Nagar and Shakarpur. Both these places are a commercial hub for small shops interspersed with residences. This area is crowded with Chartered Accounts (CA) and Company Secretary (CS) coaching institutes. Aggarwal run some of these, and many of those studying in these institutes are the children of those who own businesses in Laxmi Nagar and Shakarpur. Aggarwal own many shops selling hosiery, utensils, sweets and jewelry here. Aggarwal families moved here by the 1980s after living in different parts of Delhi. The Aggarwal caste association in this area has the highest number of registered members in Delhi (above 3,000 families in 2015). The second and third stratum do not have a separate women's wing. Men and their wives, especially those in the fourth stratum, participate in the Delhi-level association events.

What emerges from this brief charting of different Aggarwal family-business strata is that affluence is decided on the basis of time and reason for migration, which generation moved out of the agrarian economy and nature, scale and success of one's business and the manner in which one spent one's resources. From the four strata discussed above, I categorize the first two as Aggarwal business elite. These two strata no longer have family or kin in rural areas. They and their families are now located in posh gated neighborhoods in Delhi or other metropolitan cities in India. Members (predominantly men) of their family have either studied in reputed Indian universities or studied abroad in the current or/and the previous generation. More importantly, they not only have inter-generational wealth and successful businesses but also invest in either strengthening the caste community or undertake philanthropic endeavors in the larger society. The Aggarwal business elite can then be characterized as those who have "solidarity within the group, social exclusivity, and a distinctive cultural identity" (Ostrower 1995:25).

12 In her historical work on the Marwaris of Calcutta, Hardgrove (2004:8) says when she had to capture the contemporary changes in the society, she employed "appointment anthropology." Unlike a village ethnographer, whose geographical mobility would be restricted and could drop by at people's homes without fixing prior appointments, the nature of an urban ethnography and especially one amongst the elite, requires the researcher to seek prior permission and to turn up for a scheduled meeting on time. Women did not participate in the paid labor force, and their role within the household was a supervisory one, as they had a generous array of cooks, gardeners, and drivers. However, they had a busy year marked by festivals, rituals, visits to and by extended kin, 
accompanying and helping their husbands in social and business gatherings. Power minefields within the family also had to be negotiated. Permissions from mothers-in-law and mothers were required to meet the daughter and daughter-in-law. The interconnected social space of the neighborhood and the community discouraged many respondents from speaking comfortably in our initial meetings. It also made it impossible to ask questions about financial matters, transactions, scale or the ups and downs in the family business. Women usually evaded the question politely or said only the men in the family had knowledge about such things.

In the initial phases of my research when my caste was asked, I would say I am a South Indian, which would be met with an immediate smile accompanied by a response, "oh you are a Madrasi." The regional cultural identity of a "Madrasi" continues to evoke the impression of naivety, harmlessness, culture and education in North India. It is an identity which is opaque to caste and religious probing. It was assumed that I was a Hindu and I did not find it comfortable to correct this impression. The way I was perceived and the disarming role my Madrasi-ness played, made me question: How could a researcher hailing from an identifiable North Indian caste group-especially a "lower" one-from a minority religion and a lower class, study elite groups in urban spaces? Would in-depth interviews have to be replaced by distant survey methods, that permit the sociologist to stay within the defined role of researcher? Should sociologists/anthropologists constitute their field with archives, community publications, and journals alone while studying the elite? And should social units of analysis be clubs and trusts instead of the guarded Hindu joint family? Appointment anthropology and Madrasi-ness became not just practical considerations of the field, but became ways through which the sociologist negotiated her field constituted by elite respondents and in the process was constituted by/in it as a subject in return.

\section{Women in the reproduction of caste and family businesses in urban India: An overview}

Members of the Aggarwal caste in Delhi own industries, shops, trusts, schools, hospitals, printing presses, and restaurants. Numerous enterprises are named "Aggarwal" or "Gupta," so much so that elderly men in caste associations were worried that these shops were run not by Aggarwals but Chamars ${ }^{7}$ who wish to benefit from the economic might of the community. In the process, elders feared lower castes would asperse the Aggarwal caste-name by diminishing the quality of products and services. In the 1970s, the Aggarwal caste associations were formed in Delhi by the former Haryana chief minister Banarsi Das Gupta. These organizations undertook the task of carving out an Aggarwal identity. They encouraged people to use Aggarwal in their surname as opposed to their got ${ }^{8}$ (clan) names, standardized the number of got to seventeen and a half and the spelling of Aggarwal with a double "g," and finally fixed a story of descent from Maharaja Agrasen. In the process, they tried to differentiate themselves from the Marwari by their region of origin: the first hail from parts of Uttar Pradesh and Haryana, while the latter come from parts of Rajasthan, especially Mewar district. ${ }^{9}$

According to Dumont's (1980:222) thesis on "substantialization" of caste, vertical caste hierarchies are replaced by "impenetrable," "inter-dependent" blocks as if caste was an "individual" competing with another. He argues that there is a move from "structure" to 
"substance" and a horizontalization of caste. Using the substantialization theory, Gupta (2005) argues that just like the Aggarwal every caste would take pride in their origin story and myth without arranging them in vertical hierarchies. Studies on caste take substantialization as a given and these are two of the many directions in which this phenomenon has taken caste studies: firstly, it is argued that substantialization causes castes to be internally heterogeneous. Differences get articulated in the language of culture which gets expressed only in the private sphere for it is not possible to defend them in public anymore (Fuller 1996; Fuller and Narasimhan 2015; Mosse 2012); secondly, caste appears in public only in the realm of politics (Beteille 1991, Srinivas 2003). Hence it is argued that caste has lost its importance for the "upper" castes and only determines the life chances of "lower" castes. Internal heterogeneity within caste groups is critical to this article. Fuller and Narasimhan (2015) account for the internal hierarchies within the Tamil Brahmin caste through a neo-Weberian definition of "social class." That is, a social class which is also a status group leads to the making of the middle-class-caste. Fuller and Narasimhan (2015) argue there is no upward or downward mobility between the white-collar, lower-middle caste and the professional and managerial, upper-middle class Brahmins. However, in this paper, the internal heterogeneity within the Aggarwal caste is captured using a sociologically neutral category: "caste stratum." I argue that with an increase in internal differentiation and secularizing pulls of caste through changes in occupation, education, lifestyles, women's mobility and income levels those who occupy the upper stratum within a caste work towards increasing caste cohesion. The stated aim of these efforts could be community building, providing self-definitions in the everyday or consolidating numbers in a democracy. However, caste cohesion, unlike among the professional middleclass Tamil Brahmins, facilitates inter-stratum mobility through marriage, and business networks. ${ }^{10}$ It shows that caste is a resource in the urban for those in the upper and lower echelons through "networks of caste and kinship" (Jodhka 2015:230; Rutten 2003).

In this paper, I argue that women facilitate the cohesion of caste and reproduction of family business through three strategies: inter-strata "social work," intra-strata socialization and managing individuating aspirations of family members through marital choice. These roles are undertaken by women in certain caste/classes. This "politics of status maintenance" by women requires them to constantly socialise and form networks with caste others (Papanek 1979:778). Forging connections and networks is not a given but is achieved through "an endless effort at institutions ... which is necessary to produce and reproduce lasting useful relationships that can secure material or symbolic profits" (Bourdieu 1986:246). Unpaid status-reproductive roles lead to the withdrawal of women from paid employment. (Papanek 1979; Mies 1982; Abraham 2013). For example, in her study of family businesses in Arni village in Tamil Nadu, Harris-White (2002) argues that women perform three reproductive roles: reproduce and manage the capital-managing male labor; provide food as part of wages for labor; and get their daughters strategically married for business interests. In his study of Jain family business in Jaipur, Laidlaw (1995:358) says that women keep long fasts, while wealthy merchants make donations recognizing them. In this way, the man's generosity comes across as "an expression of piety" rather than a vulgar display of wealth. Women's roles show that family businesses continue to function as an economic enterprise, where the family needs to behave as a social group (Fox 1969; Hardiman 1996; Bayly, Christopher A. 1983). However unlike in the $18^{\text {th }}$ and $19^{\text {th }}$ century, this social group has to accommodate the internal hierarchies 
within the caste group as well as the individuating aspirations of its members to sustain the unity of the economic enterprise.

Women's lives are formed on the interface of overlapping and competing patriarchies of caste and class (Sangari and Vaid 1989; Rao 2003; Rege 2006) However, contemporary studies on upper-caste or elite women in India are scarce. In ethnographic studies, adopting upper-caste gender norms of "seclusion" or the "bourgeois housewife ethic" is seen as a means to upward mobility for the Dalit or non-Brahmin community (F. Osella and C. Osella 2000:79; Kapadia 1995; Still 2014; Heyer 2014). Chakravarthy (1993:580) argues that upper-caste women are objects of "moral panic" and "gateways" to the caste system. Upper-caste women in these studies appear as agency-less, acting on behalf of or acted upon by their husbands and families. Attentive to the meanings women ascribe to their actions and roles, this paper does not assume a narrative of victimhood or see women as "cultural dopes" (Kabeer 2000).

\section{Forging fictive kinship ties across caste strata through "social work."}

19 This discussion of women's "social work" focuses on two organizations: the Aggarwal caste associations in the neighborhood and Delhi; and the Rotary. ${ }^{11}$ Women attend events for both along with their husbands. However, they hold posts only in the women's wings of caste associations and the Rotary. Caste associations are male-centric spaces, and the Aggarwal caste associations are no different. Women's participation began as late as the 1990s, with the formation of a separate women's wing. Along with this development, discussions on dowry-related deaths, expensive marriages, and female feticide began appearing in Aggarwal journals. Business castes have also been historically documented for their conservative position on women's questions (Timberg 1978; Hardgrove 2004). It took the Marwaris in Calcutta a hundred years more than the Bengali Bhadralok to participate in the social reform debate (age of consent, widow remarriage, sati and women's education). They chose to participate from within the space of their caste associations and only because the mercantile autonomy of the Hindu United Family was at stake (Birla 2009; Hardgrove 2004).

In this section, I focus on women's participation in caste associations. It is noteworthy to discuss women's participation, for this is the first generation of Aggarwal women in the 40 s to 60 s age group from business families who participate in these spaces along with their husbands in Delhi. Women in the generation before them were home-bound and took care of their families. In the generation after them (daughters and daughters-in-law) women socialize with their husband's friends, occasionally volunteering with their mothers and mothers-in-law in activities of the association. At the Delhi level, the women's wing is headed and constituted primarily by women from the second stratum and living in South Delhi. This selective particiation is because in the third and second stratum women are either discouraged by families or do not have the luxury of time as they shoulder most of the domestic responsibilities.

Philanthropy has historically been associated with mercantile communities in India, serving different political functions across time. In pre-colonial India, donations and alleviating local distress helped merchants gain legitimacy within the local community, accrue abru (honor) and commercial benefits (Appadurai 1977; Bayly, Christopher A. 1983; 
Bayly, Susan 1989). In colonial India, there was a shift from gifting to charity and philanthropy that helped merchants distinguish themselves with the colonial government and contribute to the construction of local public culture and places (Frietag 1989; Rudner 1987). Ostrower (1995:17) defines philanthropy as "private giving for public purposes." Christopher A. Bayly (1983), writing about high-status Khatri and Aggarwal merchants in $18^{\text {th }}$ century India, argued that their sphere of business was not just the bazaar (market) but success in the entire society. The select society for this stratum of elite Aggarwal families was limited in scope and primarily to the caste associations. This involved both organizational and funding work and elite Aggarwal women describe their contribution as "social work."

The Hindu religious festival of Teej was organized by the women's wing of the Delhi caste association in the month of August. Yamini (62) headed the organizational committee in 2014. For elite women as organizers, the ritual significance of the event had decreased since the previous generation. Yamini had to look up the story behind the significance of the festival before writing her speech. Why did Yamini and the women's wing then continue to spend their time and money organizing Teej at the Delhi level? Yamini says:

Aggarwal women in parts of Rohini, Pitampura or Laxmi Nagar, are not allowed to step out of their homes. Even if their husbands come for the meetings they do not bring their wives. I made it a rule that men could not attend the Teej festival without their wives.

Elite women like Yamini feel they provide the morally-sanctioned cultural spaces of socialization for the less fortunate Aggarwal women in Delhi whose mobility is limited to their household or their extended kin. As facilitators of women's mobility "beyond their kitchen and families," elite women forge fictive kinship alliances based on the common experiential identity of being a woman and Aggarwal. In the process, they also create aspirational standards on what it means to be an elite Aggarwal woman for such women from lower-caste strata.

Women also help their husbands in the organization of a daylong matrimonial event called Parichay Sammelan through the DPAS and ABAS. Parichay Sammelan is an annual event which is organized in the Talkatora stadium in Delhi. Eligible Aggarwal men and women register, go on stage and introduce themselves, while families sit in the audience deciding with their children which marriage "party" to approach. In 2014 and 2015, more than six hundred girls and boys registered for this event. Until the marriage alliance is finalized, the potential spouse, and his/her family is referred to as a "party," signaling the transactional nature of the marital alliance. Aggarwal men as organizers of this event see it as a "revolutionary step" and use the language of promoting "choice" through endogamous marriage fairs. The elite women as volunteers share the feeling of benevolence of their husbands. Radhika (58) said:

Finding a suitable match for your children is the hardest thing to do. In villages you have close family ties; you check the boy/girl's family background. In cities, people don't know enough people within their community. Matrimonial agencies charge so much money. We through the caste association provide this service free of charge.

Radhika was aghast when I suggested the Parichay Sammelan as an avenue for finding a match for her daughter. It was understood that such services were for the lower stratum of Aggarwal who lacked suitable networks and capital in the urban milieu.

By volunteering their time and their husbands, by investing their money in such events, the elite women, apart from forging fictive kinship relations across the caste stratum also get to establish their family name and business affluence within their caste stratum. 
Women get an avenue to show off their creativity, avenues which were curtailed after marriage. They also get to exhibit their efficient management of help and other family members. For example, in the preparatory meeting of the event, held in South Delhi in 2015 , the topic of discussion was far from the upcoming event. Women wanted the DPAS convener to deliberate on ways in which there could be a clearer demarcation of spaces between guests and servants at weddings and other events. What followed was a lengthy discussion on managing servants, their location vis-à-vis their employers, the number of servants each of them had, if the servants accompanied them on foreign trips and if their "modern" daughters-in-law deserved the assistance of servants. In this light banter was a public articulation of their status while judging the status, household, servant and daughter-in-law management of other women in the group. Bairy (2009:1) argues that caste associations in contemporary times are an "enunciatory space," whose primary task is to speak as and on behalf of, a modern caste self. The caste associations do not just speak on behalf but are also sites for the constitution of the "modern" caste self. Projects of self-formation in the case of elite Aggarwal women play out by distinguishing themselves from internal (other elite Aggarwal women) and external others (non-elite Aggarwal women in the caste association). The elite self is made and unmade through women's familial roles and their efficiency in managing them. Being elite is a relational process that requires constant investments and being an elite woman means being wellgrounded in the family.

\section{Forging fictive kinship within caste stratum through sustained socialization}

Fictive kinship ties are strengthened not just across caste strata but also within a caste stratum through continuous socialization. The caste association and Rotary meetings institutionalized this socialization. For example, the DPAS organizes trips on an annual basis; there were some trips for which the cost per person was low enough for Aggarwal across caste strata to participate. The last such trip was to Vaishno Devi, a Hindu pilgrim site, during which enough people joined to fill seven bogies of a train. For the others in which the cost per person was high, only upper strata families participated. The last such trip was to temples in Nepal. A special train was booked starting from Safdarjung station. The head of a business group famous for a well-known chain of restaurants in India helped organize the rail requirements. The capability to organize trains exclusively for DPAS activities shows the political influence and resources the community has. This train had security guards and cooks, and did not stop to pick up other travelers. However, it stopped to meet members of Aggarwal associations in other states. Bharti (51) had gone on one of these trips and said:

When you step out of the house, you need many comforts; especially we Banias do not eat pyaaz (onion) and non-veg. Some of us don't eat lasun (garlic) either. That is why we have a special Maharaj (an upper-caste cook) to prepare our food. It is also good to meet our people in other places. Our Hill Lane, ABAS, and DPAS is all one, we keep meeting, seeing each other's faces and we have all become a family (emphasis added).

The comfort of socializing with people who share the same way of life, taste in food and values leads to the expansion of the family unit to embrace caste others within a caste stratum. 
informal spaces of socialization, involving men and their wives provide a relaxed atmosphere where business spills into the social and vice-a-versa. Informal environments created through socialization help in the discussion of business, reciprocation of favors, identification of further clients and strengthening of the economic by the affective. For example, Radhika's husband was the president of the Rotary recently, and he organized a trip for forty families to the Jim Corbett Park. On the way home, the men traveled in a separate minibus, and Radhika says their pet topic was each other's business developments, tenders, and contracts. One of the Rotary and Aggarwal caste association members was in the paper printing business and was having trouble sourcing material from Uttar Pradesh. The bus stopped in Moradabad, and amongst them, they found local contacts and sorted the problem immediately.

In business, caste and family ties structure social networks, channels of information and credit and generate a feeling of "trust" (Harris 2003). Caste membership was not a good enough reason to establish this selective trust. Trust shows a "nexus of relations" that are brought together through social obligations and "non-specific indebtedness" (Bourdieu 1986:252). These relationships get strengthened when women couch them in cultural, relational idioms sanctified by Hindu rituals. For example, Janaki and her husband Rajiv, who were new to the South Delhi circle of businesses, were asked by the ABAS President and noted Delhi businessman to join both the caste association and the Rotary circle to "make contacts and work for the community." Janaki refers to the ABAS president as bhaiya (elder brother) and ties a rakhi (cotton bracelet) on Raksha Bandhan ${ }^{12}$ every year. She says her husband was a middle man in fixing big deals, in which significant amounts of money got exchanged against sureties. She says "trust" is crucial in this process. Before making any deal, her husband would first check with bhaiya (referring to the ABAS President) about the "party's" market credibility. She says also that bhaiya's standing behind her husband meant people had reciprocal "trust" in her husband's credibility and work. Economic activity was not undertaken by isolated individuals but was embedded in social structures, historical and institutional contexts that facilitate and constrain actions (Polyani 1944; Granovetter 1992). The tenacity of caste comes in its capacity to reproduce through actively forged networks of fictive kinship ties in the urban.

\section{Steering individuating desires and marital choices}

As shown in the previous two sections, the social universe of the Aggarwal in Delhi is constituted by their caste and family ties. These networks also provide suitable marital alliances for children. Financial discussions in Aggarwal business families, unlike the Tamil Brahmins, are explicit (Fuller and Narasimhan 2015). These discussions precede the matching of kundalis (astrological charts). Families interested in a marriage alliance refer to each other as "party," and only a successful pairing of "budget" leads to a change in the abstract category of "party" to a recognizable family. Without approaching an interested party, families usually have a sense of the budget the groom's family would desire. Only if there was a match between the suggested and expected budget were marriage negotiations carried forward. Common family, friends and at times marriage brokers helped in the negotiation process. The budget refers to the money the bride's family would be ready to invest in the wedding celebrations. The dowry could be given separately both in cash or kind from the total budget cited by the bride's family. The dowry could also be a part of the budget, depending on the parties involved in the 
negotiation. The groom's side decides how they would like the budget spent and divides it into sub-headings like caterers, venue, décor, clothes, and milni ${ }^{13}$ (coming together ceremony). The groom's side could also take the entire amount and decide to organize the wedding themselves. For the Aggarwal elite in this stratum, dowries did not involve consumer durables; that was considered fit only for working class families. Their budgets were spent on expensive, elaborate weddings, a luxury car or perhaps furnished flats.

In this game of "cost analysis," the wedding budget for the bride's side exhibited: the lifelong marriage savings of the family; the success of their own business (if they were a business-class family); money they would be ready to invest for the other daughters in the family (if there were any); and the resources they had to continue giving "gifts" to their daughters and in-laws for every small and big festival after marriage ${ }^{14}$ (Bourdieu 1976:551). A big marriage budget also allowed brides' families to marry upwards. For example Kanika (52) came from a mixed family: her husband was a highly-paid professional in a private firm while her brother-in-law living in the same house, on a different floor, had his own business. She did not fit in the same stratum as women with intergenerational professional family businesses or those with manufacturing plants; however, her family had a good reputation and had been involved in the neighborhood caste association since the previous generation. Kanika knew all the other elite Aggarwal families through the caste association, kitty, ${ }^{15}$ and rotary circles. She wanted her daughter Arunima to marry into a business-class family. When Arunima informed Kanika about her Punjabi professional-class boyfriend in the neighborhood, Kanika managed to dissuade her from choosing him. Arunima was convinced by her mother, whose reluctance was not rooted in caste difference but in the fact that the boy did not earn enough to provide the lifestyle Arunima was used to and that Kanika desired for her. Studies on marriages in India argue that martial choices amongst the upper castes continue to be endogamous. At times they are expanded to embrace sub-castes or comparable castes (Nishimira 1998; Upadhya and Vasavi 2006). However, endogamous choices or weddings were read as an event in themselves. Behind such decisions lies a careful steering through the sociology of familial love and material security. Kanika found an affluent business-class family through her kitty party contact. She also found out the budget expectations, which matched theirs. Her daughter Arunima went on to become the youngest daughter-in-law in a business family in Delhi with four brothers and she was not allowed to continue working after marriage. Thus, through her neighborhood networks and a careful investment of the family's savings, Kanika married her daughter upwards.

Similarly, for the groom's side, the wedding budget reflected the market worth of their business and its potential growth; the credentials of their son; the size and location of their house; and the family reputation established through a grounding in the larger Aggarwal community. When it comes to marriages of sons, parents looked for alliances in the same class and status and not in one above them. This was despite the fact that "marrying up" would be a source of more economic and social capital for the business. This was because women realized that daughter-in-laws from families above them would be difficult to adjust to. Women secretly spoke of families in their strata who had gone on to marry above their means only to have unhappy daughters-in-law and ultimate separations. Daughters-in-law also came from professional-class families and the third stratum of Aggarwal (living in parts of Rohini, Pitampura) as long as their status was comparable, budgets matched and sons were happy with the choice. Aggarwal business 
families with successful businesses from the groom's side were ready to contribute towards big budget weddings, as long as they and their families liked the girl.

Mothers helped strike a balance between the choices of children and business interests. As seen in other studies, marital choices amongst the Aggarwal business families in South Delhi were made through the joint involvement of parents and children (Uberoi 2006; Donner 2008). As friends and confidants of their children, mothers ensured that their choices were accounted for while still securing status-appropriate marriages. For example, Renuka's (59) son, Piyush wanted a "modern" wife who would respect his parents, work with him and go partying with his friends. He came back from first "dates" arranged by parents unhappy with the women selected. Renuka had been in Delhi from the time of her marriage, without her mother-in-law's supervision. She had an active social circle and did not want to "babysit her daughter-in-law." She convinced her husband to select a daughter-in-law who was also a CA and could join the family business. Her daughter-in-law, Roshini, comes from a first-generation business family settled in Rohini.

Allowing daughters-in-law to work after marriage continues to be a contentious issue in business families. It is considered unsuitable to the status of the family, as work is associated only with profitable earnings and not self-growth or expression. Working daughters-in-law would also constitute a loss of the status reproduction roles expected of them. However, mothers-in-law realize that it would be counter-productive to the health of the family if educated daughters-in-law were actively discouraged. They encouraged daughters-in-law to pursue their hobbies by opening small projects on the side, like a design boutique, taking short-term courses like baking or joining the family business for a few hours. Daughters-in-law would then have the flexibility of work hours, keep the status of being the daughter-in-law of an elite family and be creatively entertained in the process. As opposed to their mother-in-law's generation, in which one can see a mix of frugality and display of wealth, daughters-in-law have consumptive lifestyles characterized by frequent foreign travel (accompanying their husbands on business trips), shopping trips with their friends and mother-in-law and wearing expensive jewelry in social circles and gatherings. For example, Usha's daughter-in-law, Roshini, says her life is about "kaho piyo aish karo, shopping karo, paisa udao (eat, drink, have a good time, shop and spend money)." Women in the mother and mother-in-law's generation were allowed to wear suits much later in their lives. However, the restrictions on daughter-in-law's clothing in Hill Lane were rare. They were allowed to dress according to their husbands' friend's circles. To be an elite daughter-in-law was then to lead a lifestyle that reflects the affluence of the family business.

Higher education was a certain but risky requirement for the up-gradation of family capital. If the family could afford to invest and spare both their sons for higher education, then it would be undertaken. However, it was usually the younger son if he had a temperament for studies who was sent to study abroad; the elder son would have a basic degree and be involved in the day to day management of the business. Daughters were also sent abroad for short term courses. Pursuing higher education, however, posed a risk to the continuance of the family business. For example, when Usha's younger son-sent to the US to contribute to their business of manufacturing plastic molds-seemed reluctant to come back, Usha was quick to sense it. Marriage alliances were sought and Rajat, her son, was married to Rachna on one of his visits to India. Rajat, in turn, came back to India 
to join the family business. Marriage is seen as a route for attaining social adulthood, responsibility and prioritizing the needs of the family above oneself.

With an increase in age of marriage, children's education and modern (consumptive) lifestyles, the fear of splits in families leading to a split in the business was real. A ritual to keep families united, strengthen affective ties, ensure channels of communication are functioning and in the process ensure the health of the family business was to find time to spend together as a family. In the previous generation, spending time together was a given. All food was made at home, as women were frugal and also wary of eating food prepared by unknown castes. In the current generation, however, the home was no longer the primary site of socialization. Eating out and parties were frequent and children and parents had their independent circles of friend. The ritual of evening snack sessions, going on long dinners once a month, foreign trips together and celebrating festivals were some of the things women say they initiate to be a family in the everyday. Rituals helped the different family units in the joint family-which resided on separate floors and at times managed separate manufacturing plants-to set time apart for members of the nuclear family.

\section{Conclusion}

By focusing on women's narratives from elite Aggarwal family businesses, this article shows how women, despite being invisibilized in family businesses, play an important role in their reproduction. An increase in internal heterogeneities in urban caste groups like the Aggarwal causes the upper strata to forge cohesion by strengthening inter-strata caste and family ties. Three strategies of reproduction used by women along with their families are discussed: inter-strata "social work"; intra-strata sustained socialization; and a negotiation of children's individuation desires. This article shows how caste continues to act as a resource for the upper caste despite internal heterogeneities and the secularizing pulls of the urban.

As agents in the processual structuring of caste and family businesses, elite upper-caste Aggarwal women in the older generation are not passive. However, unlike Ostrander's (1984) elite women, they do not sit on the boards of cultural and educational organizations. Their morally permissible sphere of socialization and mobility continues to be within extended caste and kinship networks. In the younger generation of women, however, there is a waning interest in these caste-marked spaces and an increase in individualized utilization of time and resources. Would this change the nature of capital dependence in family businesses brought about by the "modernity" of its caste-ed actors? Attention to changing elite gendered subjectivities and the new vocabularies of caste-ed selves reveals the secularizing pulls of capital on traditional institutions like Indian family businesses. 


\section{BIBLIOGRAPHY}

Abraham, Vinoj. 2013. “Missing Labour or Consistent 'De-Feminisation'?” Economic and Political Weekly 48(31): 99-108.

Appadurai, Arun. 1977. "Kings, Sects and Temples in South India, 1350-1700 A.D." Indian Economic and Social History Review 14(1): 47-74.

Bairy, Ramesh T.S. 2009. "Brahmins in the Modern World: Association as Enunciation." Contributions to Indian Sociology 43(1): 89-120.

Bairy, Ramesh T.S. 2010. Being Brahmin, Being Modern: Exploring the Lives of Caste Today. Delhi: Routlege.

Bayly, Christopher A. 1983. Rulers, Townsmen and Bazaars: North Indian Society in the Age of British Expansion. Cambridge: Cambridge University Press.

Bayly, Susan. 1983. “The History of Caste in South Asia.” Modern Asian Studies 17(3): 519-27.

Bayly, Susan. 1989. Saints, Goddesses and Kings: Muslims and Christians in South Indian Society, 1700-1900. Cambridge: Cambridge University Press.

Beteille, Andre. 1991. "The Reproduction of Inequality: Occupation, Caste and Family." Contributions to Indian Sociology 25(1): 3-28.

Birla, Ritu. 2009. Stages of Capital: Law, Culture and Market Governance in Late Colonial India. Durham: Duke University Press.

Bourdieu, Pierre. 1976. "Marriage Strategies as Strategies of Social Reproduction." Pp. 132-41 in Family and Society: Selections from the Annales, edited by R. Forster and O. Ranum. Baltimore: The John Hopkins University Press.

Bourdieu, Pierre. 1986. "The Forms of Capital." Pp. 241-58 in Handbook of Theory and Research for the Sociology of Education, edited by J. Richardson. New York: Greenwood.

Chakravarthy, Uma. 1993. "Conceptualising Brahmanical Patriarchy in Early India: Gender, Class and State." Economic and Political Weekly 28(14): 579-85.

Ciotti, Maniela. 2010. Retro Modern India: Forging the Low Caste Self. London and New York: Routledge.

Daljit, Han Donker and Ravi Saxena. 2012. “Corporate Boards in India: Blocked by Caste.” Economic and Political Weekly 47(31): 39-43.

Damodaran, Harish. 2008. India's New Capitalists: Caste, Business and Industry in a Modern Nation. UK: Palgrave Macmillan.

Das Gupta, Chirashree. 2013. "The Tenacity of the Hindu Undivided Family: Gender, Religion and Tax Concessions." Economic and Political Weekly 48(40): 73-75.

Donner, Henrike. 2008. Domestic Goddesses: Maternity, Globalization and Middle-class Identity. Farnham: Ashgate Publishing Limited.

Dumont, Louis. 1980. Homo Hierarchicus: The Caste System and its Implications. Chicago: The University of Chicago Press. 
Dupont, Véronique. 2004. “Socio-Spatial Differentiation and Residential Segregation in Delhi: A Question of Sale?" Geoforum 35: 157-75.

Fox, Richard G. 1969. From Zamindar to Ballot Box: Community Change in a North Indian Market Town. Ithaca: Cornell University Press.

Frietag, Sandria. 1989. Collective Action and Community: Public Arenas and the Emergence of Communialism in North India. Berkeley: University of California Press.

Fuller, Chris J. 1996. Caste Today. Delhi: Oxford University Press.

Fuller, Chris J. and Haripriya Narasimhan. 2015. Tamil Brahmans: The Making of a Middle-Class Caste. Chicago: University of Chicago Press.

Gopal, Madan. 1977. Sir Chhotu Ram: A Political Biography. Punjab: B.R. Publishing.

Granovetter, Mark. 1992. "Economic Institutions as Social Constructions: A Framework for Analysis.” Acta Sociologica 35: 3-11.

Gupta, Dipankar. 2004. Caste in Question: Identity of Hierarchy. New Delhi: Sage Publications. Gupta, Dipankar. 2005. “Whither the Indian Village: Culture and Agriculture in 'Rural' India." Economic and Political Weekly 40(8): 751-58.

Hardgrove, Anne. 2004. Community and Public Culture: The Marwaris in Calcutta. Delhi: Oxford. Hardiman, David. 1996. Feeding the Baniyas: Peasants and Usurers in Western India. Delhi: Oxford University Press.

Harris, John. 2003. "Widening the Radius of Trust: Explorations of Trust and Indian Business." Journal of the Royal Anthropological Institute 9: 1-14.

Harris-White, Barbara. 2002. India Working: Essays on Society and Economy. Delhi: Cambridge University Press.

Heyer, J. 2014. "Dalit Women Becoming Housewives: Lessons from the Tiruppur region, 1981/2 to 2008/9." Pp. 208-36 in Dalits in Neoliberal India: Mobility or Marginalisation? edited by C. Still. London, New Delhi: Routledge. Delhi: Orient Blackswan.

Jodhka, Surinder. 1995. "Who Borrows? Who Lends? Changing Structures of Informal Credit in Rural Haryana." Economic and Political Weekly 30(39): A123-32.

Jodhka, Surinder. 2015. Caste in Contemporary India, Delhi: Routledge.

Kabeer, Naila. 2000. The Power to Choose: Bangladeshi Women and Labour Market Decisions in Dhaka and London. London: Verso.

Kapadia, Karin. 1995. Shiva and Her Sisters: Gender, Caste and Class in Rural South India, San Francisco, Oxford: Westview Press.

Khanna, Tarun and Krishna Palepu. 2000. "Is Group Affiliation Profitable in Emerging Markets? An Analysis of Diversified Indian Business Groups.” The Journal of Finance 55: 867-91.

Laidlaw, James. 1995. Riches and Renunciation: Religion, Economy and Society among the Jains. Oxford: Clarendon Press.

Markovits, Claude. 2010. "What about the Merchants? A Mercantile Perspective on the Middle Class of Colonial India." Pp. 118-31, The Middle Class in Colonial India, edited by S. Joshi. New Delhi: Oxford University Press.

Markovits, Claude. 2008. Merchants, Traders, Entrepreneurs: Indian Business in the Colonial Era. New York: Palgrave Macmillan. 
Mies, Maria. 1982. "The Dynamics of the Sexual Division of Labour and Integration of Rural Women into the World Market." Pp 1-28 in Women and Development: The Sexual Division of Labour in Rural Societies, edited by L. Beneria. ILO: Praeger Scientific.

Mosse, David. 2012. The Saint in the Banyan Tree: Christianity and Caste Society in India. Berkeley: University of California Press.

Naudet, Jules and Claire-Lise Dubost. 2016. "The Indian Exception: The Densification of the Network of Corporate Interlocks and the Specificities of the Indian Business System." SocioEconomic Review 2016: 1-30.

Nishimura, Yuko. 1998. Gender, Kinship and Rroperty Rights: Nagarattar Womanhood in South India. Delhi: Oxford University.

Osella, Caroline and Filippo Osella. 2000. Social Mobility in Kerala: Modernity and Identity in Conflict. London: Pluto Press.

Ostrander, Susan. 1984. Women of the Upper Class. Philadelphia: Temple University Press.

Ostrower, Francie. 1995. Why the Wealthy Give: The Culture of Elite Philanthropy. Princeton: Princeton University Press.

Papanek Hanna. 1979. “Status Production: The 'Work' and 'Non-work' of Women.” Signs 4(4): 77581.

Polyani, Karl. 1944. The Great Transformation: The Political and Economic Origins of Our Time. Boston, MA: Beacon Press.

Rao, Anupama. 2003. Gender and Caste. Vol. 1, Issues in Contemporary Indian Feminism. New Delhi: Kali for Women.

Rege, Sharmila. 2006. Writing Caste/Writing Gender: Narrating Dalit Women's Testimonies. Delhi: Zubaan.

Rudner, David. 1987. "Religious Gifting and Inland Commerce in Seventeenth Century South India." Journal of Asian Studies 46(2): 361-79.

Rutten, Mario. 2003. Rural Capitalists in Asia: A Comparative Analysis on India, Indonesia, and Malaysia. London: Routledge.

Sangari, Kusum and Sudesh Vaid. 1989. Recasting Women: Essays in Indian Colonial History. New Delhi: Kali for Women.

Srinivas, M.N. 2003. “An Obituary on Caste as a System." Economic and Political Weekly 38(5): 45559.

Still, Clarinda. 2014. Dalit Women: Honour and Patriarchy in South India. New Delhi: Social Science Press.

Timberg, Thomas A. 1978. The Marwaris: From Traders to Industrialists. New Delhi: Vikas.

Tripathi, Dwijendra. 1984. Business Communities of India: A Historical Perspective. New Delhi: Oxford University Press.

Uberoi, Patricia. 2006. Freedom and Destiny: Gender, Family, and Popular Culture in India. Delhi: Oxford University Press.

Upadhya, Carol and A.R. Vasavi. 2006. Work, Culture, and Sociality in the Indian IT Industry: A Sociological Study. Final report to Indo-Dutch Programme for Alternatives to Development. Retrieved August 6, 2008. (http://www.nias.res.in/docs/idpadfinalreport.pdf). 
Vithayathil, Trina and Gayatri Singh. 2012. "Spaces of Discrimination: Residential Segregation in Indian Cities." Economic and Political Weekly 47(37): 60-66.

Zelizer, Vivian. 2005. Economic Lives: How Culture Shapes the Economy. Princeton and Oxford: Princeton University Press.

\section{NOTES}

1. "Hill Lane" is a pseudonym for the studied South Delhi neighborhood. Names and identifiable markers of all respondents have been changed to maintain anonymity.

2. The Aggarwals draw their descent-based lineage back to Maharaja Agrasen.

3. The Punjabi Bagh Aggarwal women's association organized an annual fair where Aggarwal, Jain and Punjabi women rented shops and sold things they had made or designed like jewellery, sarees, suits and bags. These were advertised as "lifestyle" festivals.

4. These strata are not as neatly defined, comprehensive or bound as might appear in the description below. They are based on the genealogical narratives of select Aggarwal families residing in each of these areas and hence do not claim to represent the entire Aggarwal population or their reasons for migration.

5. Chandni Chowk is a Lok Sabha constituency populated by Muslim and merchant-caste families. This claim by the Aggarwal should be read in the context of their increasing Hindu-ization and close proximity to the political Hindu right.

6. In 1934, Chhotu Ram a famous Jat leader contributed to the agrarian laws in Punjab. In that year he helped draft and pass the Punjab Relief Indebtedness Act and in 1936 the Punjab Debtor's Protection Act to give peasants relief from the moneylenders (Gopal 1977). Money lending as a profession and Aggarwals by extension were severely affected by this.

7. Chamar is a blanket term used for Dalits working with leather and tanning Dalits. The Aggarwal use it derogatorily to refer to anyone who is a Dalit.

8. The eighteen Aggarwal gots are Garg, Bansal, Bindal, Bhandal, Dharan, Airan, Goyal, Goyan, Jindal, Singhal, Kansal, Kucchal Agrahari, Madhukul, Mangal, Mittal, Nangal, Tayal and Tingle

9. However, the neat distinction between Aggarwal and Marwari, , gets fuzzy in the everyday, with Marwaris actively participating in activities of the Aggarwal caste association, Aggarwal using varna (the four-caste classifications) category Vaish instead of the jati (the endogamous caste unit) category Aggarwal in public events to encourage Marwaris, Maheshwaris, and Jains to participate in their events and inter-marriages. The differences between Marwari and Aggarwal further get complicated with categories like "Marwari Aggarwal" or "Aggarwal Marwari."

10. It would be erroneous to suggest a monolithic model for the diverse "upper"-caste groups, and I argue specifically for business castes and family businesses like the Aggarwal who unlike the middle class have a "narrow base of recruitment of caste" (Markovits 2010:128).

11. The Rotary Club is a part of the Rotary International, and in India, it has been divided into districts and zones. In the specific zone that my respondents belong to, membership is open to all; however, apart from two to three Punjabi families, the rest are all Aggarwal. Membership through invitation means that it is an intimate circle of known people. Rotary membership overlaps with that of the caste associations. Families with successful intergenerational industries, however, were reluctant to participate in Rotary meetings, considering it a waste of their time. It was the men in professional firms along with their wives who were more inclined to participate.

12. Raksha means to protect, and Bandan means a bond. It is a Hindu religious festival between a brother and sister.

13. When the groom's family enters the venue for the wedding, they are greeted by members of the bride's family. Usually, it was a meeting of the men from both sides, in which gifts (in the 
form of money in envelopes or clothing) were given to all the close family members of the groom's side.

14. In Aggarwal family businesses, for every small and big festival the bride's side sends gifts for their daughter and her in-laws. These "gifts" are expensive especially in the first year of marriage or after the birth of a child. They continued for the rest of the life of the bride though the value of the "gifts" given might decrease. Women as mothers ensure that appropriate "gifts" were sent on every occasion.

15. A kitty party is a women's gathering that usually happens once a month. The "kitty" refers to the amount each woman contributes on a monthly basis. Once a year when it is her turn she gets a lump-sum amount. In the South Delhi neighborhood, there were a couples' kitties, bhajan (session of religious songs) kitties, inter-generational mother-in-law and daughter-in-law kitties. Membership in these kitties required the husbands to be members of the Aggarwal association at the Delhi level. However, the lane kitties (involving members living in the same lane in the neighborhood) included neighborhood Punjabi women.

\section{ABSTRACTS}

This article explores the social reproductive roles performed by elite "upper"-caste Aggarwal women in family businesses in Delhi. With the substantialization of caste, there is an increase in heterogeneities within caste groups. By focussing on women's associational and familial roles in a South Delhi neighborhood three strategies of reproduction are discussed: first, forging interstrata fictive kinship ties for caste cohesion through women's "social work"; second, forging intra-strata fictive kinship ties for business opportunities through sustained interactions; and third, steering the individuating aspirations of children around marital choices for the unity of the joint family and business. These strategies of elite reproduction highlight the secularizing pulls on gender and caste in urban contexts, despite the dependence of family businesses on caste and family ties. Furthermore, by focusing on women in family businesses, this article shows that while they are not passive victims of caste patriarchy neither are they invisible in the malecentric family businesses.

\section{INDEX}

Keywords: upper caste, elite, women, social reproduction, family businesses

\section{AUTHOR}

\section{UJITHRA PONNIAH}

Ph.D. Research Scholar at the Center for Study of Social Systems (CSSS), Jawaharlal Nehru University (JNU), New Delhi. 